Article

\title{
Chemical and Biological Characterization of Melaleuca alternifolia Essential Oil
}

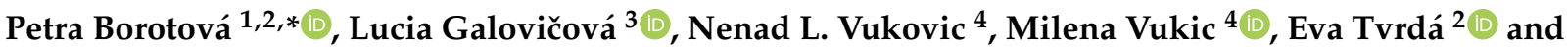 \\ Miroslava Kačániová ${ }^{3,5, *(1)}$
}

1 AgroBioTech Research Centre, Slovak University of Agriculture, Tr. A. Hlinku 2, 94976 Nitra, Slovakia

2 Faculty of Biotechnology and Food Sciences, Institute of Applied Biology, Slovak University of Agriculture, Tr. A. Hlinku 2, 94976 Nitra, Slovakia; eva.tvrda@uniag.sk

3 Faculty of Horticulture and Landscape Engineering, Institute of Horticulture, Slovak University of Agriculture, Tr. A. Hlinku 2, 94976 Nitra, Slovakia; l.galovicova95@gmail.com

4 Department of Chemistry, Faculty of Science, University of Kragujevac, 34000 Kragujevac, Serbia; nvchem@yahoo.com (N.L.V.); milena.vukic@pmf.kg.ac.rs (M.V.)

5 Department of Bioenergy, Food Technology and Microbiology, Institute of Food Technology and Nutrition, University of Rzeszow, 4 Zelwerowicza Str., 35-601 Rzeszow, Poland

* Correspondence: petra.borotova@uniag.sk (P.B.); miroslava.kacaniova@gmail.com (M.K.)

Citation: Borotová, P.; Galovičová, L.; Vukovic, N.L.; Vukic, M.; Tvrdá, E.; Kačániová, M. Chemical and Biological Characterization of Melaleuca alternifolia Essential Oil. Plants 2022, 11, 558. https://doi.org/ $10.3390 /$ plants 11040558

Academic Editors: Jésus Palá-Pául and Joe Brophy

Received: 31 January 2022

Accepted: 18 February 2022

Published: 20 February 2022

Publisher's Note: MDPI stays neutral with regard to jurisdictional claims in published maps and institutional affiliations.

Copyright: (C) 2022 by the authors. Licensee MDPI, Basel, Switzerland. This article is an open access article distributed under the terms and conditions of the Creative Commons Attribution (CC BY) license (https:/ / creativecommons.org/licenses/by/ $4.0 /)$.

\begin{abstract}
The essential oil of Melaleuca alternifolia, commonly known as tea tree oil, has many beneficial properties due to its bioactive compounds. The aim of this research was to characterize the tea tree essential oil (TTEO) from Slovakia and its biological properties, which are specific to the chemical composition of essential oil. Gas chromatography/mass spectroscopy revealed that terpinen-4-ol was dominant with a content of $40.3 \%$. $\gamma$-Terpinene, 1,8-cineole, and $p$-cymene were identified in contents of $11.7 \%, 7.0 \%$, and $6.2 \%$, respectively. Antioxidant activity was determined at $41.6 \%$ radical inhibition, which was equivalent to $447 \mu \mathrm{g}$ Trolox to $1 \mathrm{~mL}$ sample. Antimicrobial activity was observed by the disk diffusion method against Gram-positive $\left(\mathrm{G}^{+}\right)$, Gram-negative $\left(\mathrm{G}^{-}\right)$ bacteria and against yeasts, where the best antimicrobial activity was against Enterococcus faecalis and Candida albicans with an inhibition zone of $10.67 \mathrm{~mm}$. The minimum inhibitory concentration showed better susceptibility by $\mathrm{G}^{+}$and $\mathrm{G}^{-}$planktonic cells, while yeast species and biofilm-forming bacteria strains were more resistant. Antibiofilm activity was observed against Pseudomonas fluorescens and Salmonella enterica by MALDI-TOF, where degradation of the protein spectra after the addition of essential oil was obtained. Good biological properties of tea tree essential oil allow its use in the food industry or in medicine as an antioxidant and antimicrobial agent.
\end{abstract}

Keywords: tea tree; essential oil; antioxidant; antimicrobial

\section{Introduction}

Melaleuca alternifolia (tea tree) is a small tree of the family Myrtaceae native to Australia. The tea tree essential oil (TTEO) produced from its leaves can be classified into three major chemotypes: terpinen-4-ol, terpinolene, and 1,8-cineole [1]. Other chemotypes are a combination of dominant and nondominant constituents, with various compositions [2]. The terpinen-4-ol chemotype is dominant and also medicinally more interesting [3]. In medicine, TTEO is used against acne [4], reduces contact dermatitis [5], and improves wound healing [6].

Terpinen-4-ol is a naturally occurring monoterpene alcohol with good antimicrobial properties. It is effective against methicillin-resistant $S$. aureus [7] and fluconazole-resistant C. albicans [8]. It can also inhibit proinflammatory mediators [9] and can act as a potential anticancer agent [10]. $\alpha$-Terpinene and $\gamma$-terpinene are monoterpene isomers that naturally occur in various essential oils. Both isomers have strong antioxidant activity and can have an effect on the protection of DNA oxidation [11]. Their next isomer is terpinolene 
( $\delta$-terpinene), naturally found in herbs, which is frequently used as a flavoring agent. It has high antioxidant capacity and potential antiproliferative properties [12]. 1,8-Cineole, a bicyclic monoterpenoid also known as eucalyptol, is commonly used in the treatment of respiratory diseases [13]. It has good antioxidant and anti-inflammatory properties [14]. Antibiofilm activity against Streptococcus pyogenes was also observed [15]. P-Cymene belongs to a group of alkylbenzenes. It can be found in more than 100 plant species, and it possesses a broad spectrum of antioxidant, antimicrobial, antiparasitic, and anti-inflammatory activities [16]. Due to bioactive compounds such as terpinen-4-ol, $\alpha$-terpinolene, $\alpha$-terpinene, and $\gamma$-terpinene, TTEOs have potentially strong antioxidant properties [17]. This natural antioxidant has better properties than synthetic butylated hydroxytoluene, which gives the possibility to prevent food oxidation [18]. The composition of TTEO results in good antimicrobial activity against bacteria, fungal, or viral pathogens [19]. TTEO is able to inhibit respiration and increase membrane permeability, which results in the inhibition of microbial metabolism [20]. Many bacteria are able to grow in the form of biofilm, which is less vulnerable to adverse effects from the outer environment. The inhibition activity of TTEO on pathogenic biofilm was observed against $P$. aeruginosa, S. aureus, C. albicans, and $V$. harveyi [21]. TTEO is also able to inhibit bacteria in the form of biofilm. TTEO is active against biofilm-forming S. aureus [22], E. coli [23], or yeast C. albicans [24].

Pseudomonas fluorescens is a Gram-negative motile bacterium that can form biofilm in soil and water habitats. It can influence food spoilage, water quality, plant diseases, and create nosocomial infections [25]. P. fluorescens in the form of biofilm can be found to cause spoilage of milk and dairy products [26]. Salmonella enterica, a rod-shaped Gramnegative bacterium, is the main cause of acute foodborne illness and is a source of infection from poultry meat [27]. It can form biofilm even in low temperatures and can cause food spoilage in the refrigerator [28]. The biofilm can be formed on glass and wooden surfaces, which can cause cross-contamination of vegetables [29]. Essential oils have been used for many years in medicine, culinary, and the food industry, due to their beneficial properties. The aim of this research was to characterize EO from Slovakia and its biological properties. The chemical composition of TTEO was determined. Antioxidant and antimicrobial activity were described. This is the first study where the antibiofilm activity of TTEO against P. fluorescens and S. enterica was determined by MALDI-TOF MS, where molecular changes in protein structure were observed.

\section{Results}

\subsection{Chemical Composition}

In the TTEO, 47 volatile organic compounds were identified, which was $96.5 \%$ of the total composition (Table 1, trace components below $0.1 \%$ are not listed). The dominant constituent was terpinen- 4 -ol with $40.3 \%$. The TTEO also contained $11.7 \% \gamma$-terpinene, $7.0 \%$ 1,8-cineole, and $6.2 \%$ p-cymene as major components.

\subsection{Antioxidant Activity}

The antioxidant activity measured by DPPH radical scavenging was determined at $41.6 \%$ inhibition, which was equivalent to $447 \mu \mathrm{g}$ Trolox to $1 \mathrm{~mL}$ sample.

\subsection{Antimicrobial Activity Analyzed by Disk Diffusion Method}

The highest antimicrobial activity was observed against $E$. faecalis and $C$. albicans with an inhibition zone of $10.67 \mathrm{~mm}$. All other tested microorganisms except $M$. luteus exhibited moderate activity with inhibition zones in the range of 6.00 to $9.33 \mathrm{~mm}$ (Table 2). M. luteus exhibited the highest resistance with an inhibition zone of $4.67 \mathrm{~mm}$.

\subsection{Antimicrobial Activity Analyzed by Broth Microdilution Method}

The lowest concentration of TTEO with 50\% inhibition of microorganisms (MIC 50) was determined for P. aeruginosa $(10.46 \mu \mathrm{L} / \mathrm{mL})$, S. aureus $(11.52 \mu \mathrm{L} / \mathrm{mL})$, and S. enterica $(11.82 \mu \mathrm{L} / \mathrm{mL})$. The lowest MIC 90 values were observed for P. aeruginosa $(12.32 \mu \mathrm{L} / \mathrm{mL})$, 
S. aureus $(14.26 \mu \mathrm{L} / \mathrm{mL})$, and P. fluorescens $(15.46 \mu \mathrm{L} / \mathrm{mL})$. Generally, $\mathrm{G}^{+}$and $\mathrm{G}^{-}$bacteria seemed to be more susceptible against TTEO compared to yeasts, where MIC 50 reached concentrations above $20 \mu \mathrm{L} / \mathrm{mL}$. Additionally, biofilm-forming bacterial strains were more resistant to TTEO compared to planktonic bacteria with MIC 50 values of $25.46 \mu \mathrm{L} / \mathrm{mL}$ for P. fluorescens and $23.18 \mu \mathrm{L} / \mathrm{mL}$ for S. enterica (Table 3).

Table 1. Chemical composition of TTEO.

\begin{tabular}{|c|c|c|}
\hline Retention Index & Identified Compound & $\%$ \\
\hline 1178 & Terpinen-4-ol & $40.3 \pm 0.02$ \\
\hline 1060 & $\gamma$-Terpinene & $11.7 \pm 0.02$ \\
\hline 1033 & 1,8-Cineole & $7.0 \pm 0.01$ \\
\hline 1023 & p-Cymene & $6.2 \pm 0.02$ \\
\hline 1016 & $\alpha$-Terpinene & $3.9 \pm 0.01$ \\
\hline 1189 & $\alpha$-Terpineol & $3.9 \pm 0.02$ \\
\hline 938 & $\alpha$-pinene & $3.4 \pm 0.01$ \\
\hline 1088 & $\alpha$-Terpinolene & $2.2 \pm 0.01$ \\
\hline 1443 & Aromadendrene & $2.0 \pm 0.01$ \\
\hline 1498 & Ledene & $1.9 \pm 0.01$ \\
\hline 1525 & $\delta$-Cadinene & $1.9 \pm 0.01$ \\
\hline 1028 & $\alpha$-Limonene & $1.6 \pm 0.01$ \\
\hline 980 & $\beta$-Pinene & $1.2 \pm 0.01$ \\
\hline 992 & $\beta$-Myrcene & $0.8 \pm 0.01$ \\
\hline 1183 & p-Cymen-8-ol & $0.8 \pm 0.01$ \\
\hline 1503 & Bicyclogermacrene & $0.8 \pm 0.01$ \\
\hline 1530 & cis-Calamenene & $0.8 \pm 0.01$ \\
\hline 1422 & (e)-Caryophyllene & $0.7 \pm 0.01$ \\
\hline 926 & $\alpha$-Thujene & $0.6 \pm 0.01$ \\
\hline 1408 & $\alpha$-Gurjunene & $0.6 \pm 0.01$ \\
\hline 1098 & Linalool & $0.5 \pm 0.01$ \\
\hline 1379 & $\alpha$-Copaene & $0.5 \pm 0.01$ \\
\hline 1652 & $\alpha$-Eudesmol & $0.4 \pm 0.01$ \\
\hline 948 & Camphene & $0.3 \pm 0.01$ \\
\hline 977 & Sabinene & $0.3 \pm 0.01$ \\
\hline 1490 & $\beta$-Selinene & $0.3 \pm 0.01$ \\
\hline 1504 & $\alpha$-Muurolene & $0.3 \pm 0.01$ \\
\hline 1542 & $\alpha$-Cadinene & $0.3 \pm 0.01$ \\
\hline 1004 & $\alpha$-Phellandrene & $0.2 \pm 0.01$ \\
\hline 1439 & $\gamma$-Elemene & $0.2 \pm 0.01$ \\
\hline 1456 & $\alpha$-Humulene & $0.2 \pm 0.01$ \\
\hline 1577 & Spathulenol & $0.2 \pm 0.01$ \\
\hline 1593 & Viridiflorol & $0.2 \pm 0.01$ \\
\hline 1353 & $\alpha$-Cubebene & $0.1 \pm 0.01$ \\
\hline 1371 & Isoledene & $0.1 \pm 0.01$ \\
\hline
\end{tabular}

\subsection{Analysis of Biofilm Degradation}

The effect of TTEO against biofilm-forming bacteria $P$. fluorescens was evaluated with MALDI-TOF MS Biotyper ${ }^{\circledR}$. Spectra of control groups (planktonic cells and biofilm untreated by TTEO) evolved equally (spectra are not shown), so control planktonic cells were used as a control for comparison of molecular changes in biofilm.

Based on the analysis of the mass spectra of the biofilm on individual days (Figure 1A-F), we can observe that the experimental group from the glass surface developed during the experiment very similarly to the control planktonic spectrum up to Day 9. On Days 12 and 14 of the experiment, a change in the mass spectrum was observed, which indicated a change in the protein composition in the biofilm due to long-term exposure to TTEO.

In the experimental group from the wooden surface, we observed a significantly smaller number of peaks with low intensity compared to the control planktonic spectrum from the Day 3 of the experiment, which proves the influence of TTEO on biofilm homeostasis. On Day 14 of the experiment, the number of peaks increased again, which may 
indicate that the essential oil had a limited duration of action, and the biofilm was able to adapt to adverse conditions.

Table 2. Antimicrobial activity of TTEO.

\begin{tabular}{cccc}
\hline Microorganism & Inhibition Zone & Activity of EO & Control \\
\hline Gram-positive bacteria & & & \\
\hline Bacillus subtilis & $9.33 \pm 1.70$ & $* *$ & $31 \pm 3.0$ \\
Enterococcus faecalis & $10.67 \pm 1.25$ & $* * *$ & $28 \pm 0.5$ \\
Micrococcus luteus & $4.67 \pm 0.47$ & $*$ & $26 \pm 2.0$ \\
Staphylococcus aureus & $7.33 \pm 0.47$ & $* *$ & $31 \pm 1.0$ \\
\hline Gram-negative bacteria & & & \\
\hline Pseudomonas aeruginosa & $6.00 \pm 0.82$ & $* *$ & $22 \pm 1.0$ \\
Yersinia enterocolitica & $6.00 \pm 0.82$ & $* *$ & $25 \pm 1.5$ \\
Salmonella enterica & $7.33 \pm 1.25$ & $* *$ & $27 \pm 2.0$ \\
Serratia marcescens & $6.67 \pm 0.94$ & $* *$ & $25 \pm 1.0$ \\
Pseudomonas fluorescens biofilm & $6.00 \pm 0.00$ & $* *$ & \\
Salmonella enterica biofilm & $6.00 \pm 0.82$ & $* *$ & $31 \pm 1.5$ \\
\hline Yeasts & & & $31 \pm 3.0$ \\
\hline Candida albicans & $10.67 \pm 1.70$ & $* * *$ & $31 \pm 1.0$ \\
\hline Candida glabrata & $7.67 \pm 2.62$ & $* *$ & $*$ dida krusei \\
Candida tropicalis & $6.33 \pm 0.47$ & $* *$ & \\
\hline
\end{tabular}

${ }^{*}$ Weak activity (1-5 mm zone); ${ }^{* *}$ moderate activity (5-10 $\mathrm{mm}$ zone); ${ }^{* * *}$ strong activity (over $10 \mathrm{~mm}$ ); antibiotics used as control: cefoxitin for $\mathrm{G}^{-}$bacteria, gentamicin for $\mathrm{G}^{+}$bacteria, fluconazole for yeasts.

Table 3. Minimal inhibitory concentrations of TTEO.

\begin{tabular}{ccc}
\hline Microorganism & MIC $\mathbf{5 0}(\boldsymbol{\mu L} / \mathbf{m L})$ & MIC $\mathbf{9 0}(\boldsymbol{\mu L} / \mathbf{m L})$ \\
\hline Gram-positive bacteria & & \\
\hline Bacillus subtilis & 14.25 & 18.36 \\
Enterococcus faecalis & 15.86 & 18.45 \\
Micrococcus luteus & 13.58 & 18.68 \\
Staphylococcus aureus & 11.52 & 14.26 \\
\hline Gram-negative bacteria & & \\
Pseudomonas aeruginosa & 10.46 & 12.32 \\
Yersinia enterocolitica & 12.25 & 15.46 \\
Salmonella enterica & 11.82 & 16.36 \\
Serratia marcescens & 13.45 & 16.24 \\
Pseudomonas fluorescens biofilm & 25.46 & 28.59 \\
Salmonella enterica biofilm & 23.18 & 25.43 \\
\hline Yeasts & & \\
\hline Candida albicans & 22.52 & 26.76 \\
Candida glabrata & 24.33 & 29.85 \\
Candida krusei & 23.15 & 26.32 \\
Candida tropicalis & 21.86 & 27.46 \\
\hline
\end{tabular}

The constructed dendrogram (Figure 2) showed that the glass experimental group had shorter MSP distances than the control group after Day 9. On Days 12 and 14, the MSP distance of the experimental groups was significantly higher compared to the control group. Based on the findings, we can state that after longer exposure, the inhibitory effect of the essential oil on the structure of the biofilm appeared on the glass surface. 

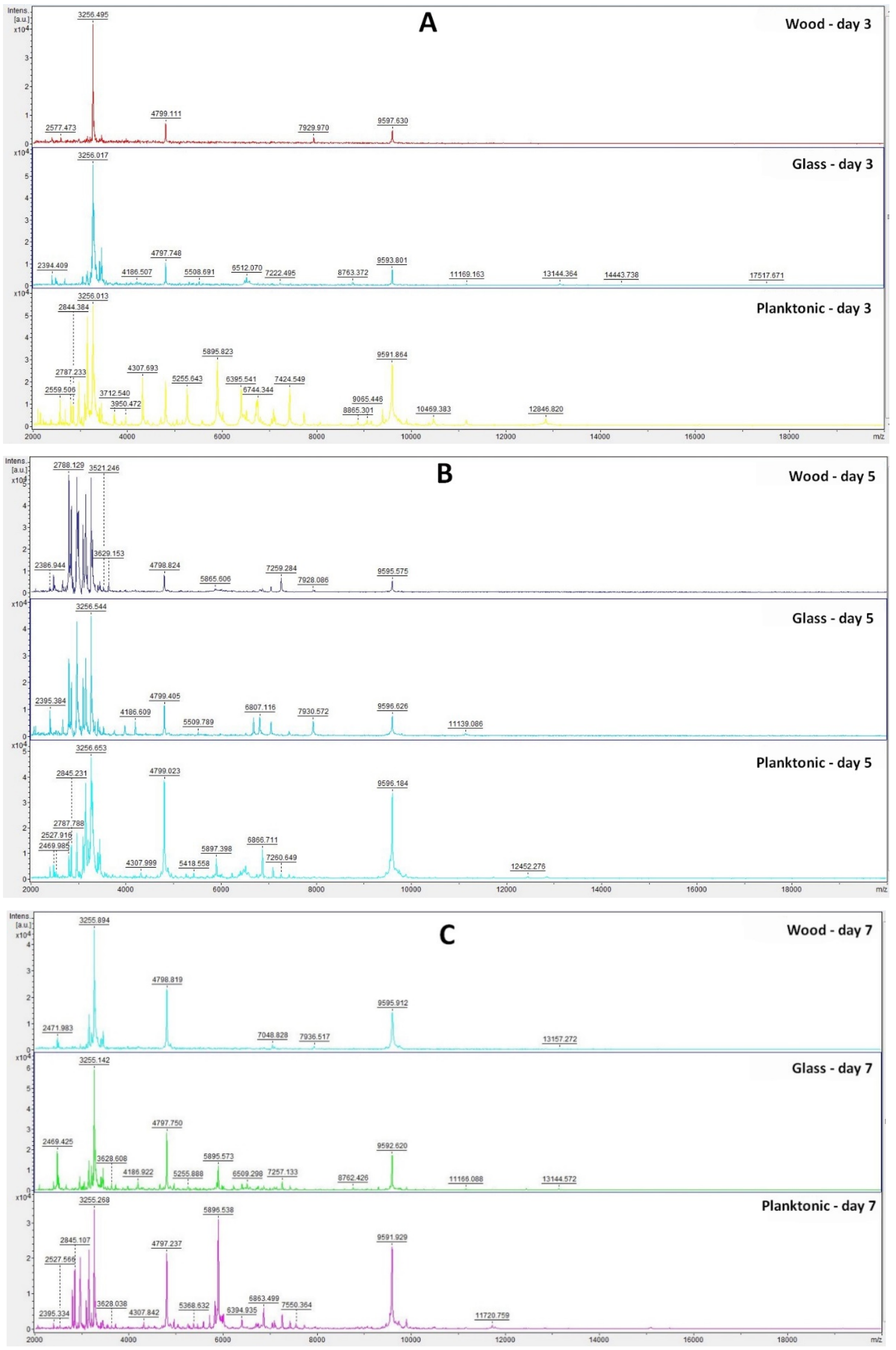

Figure 1. Cont. 

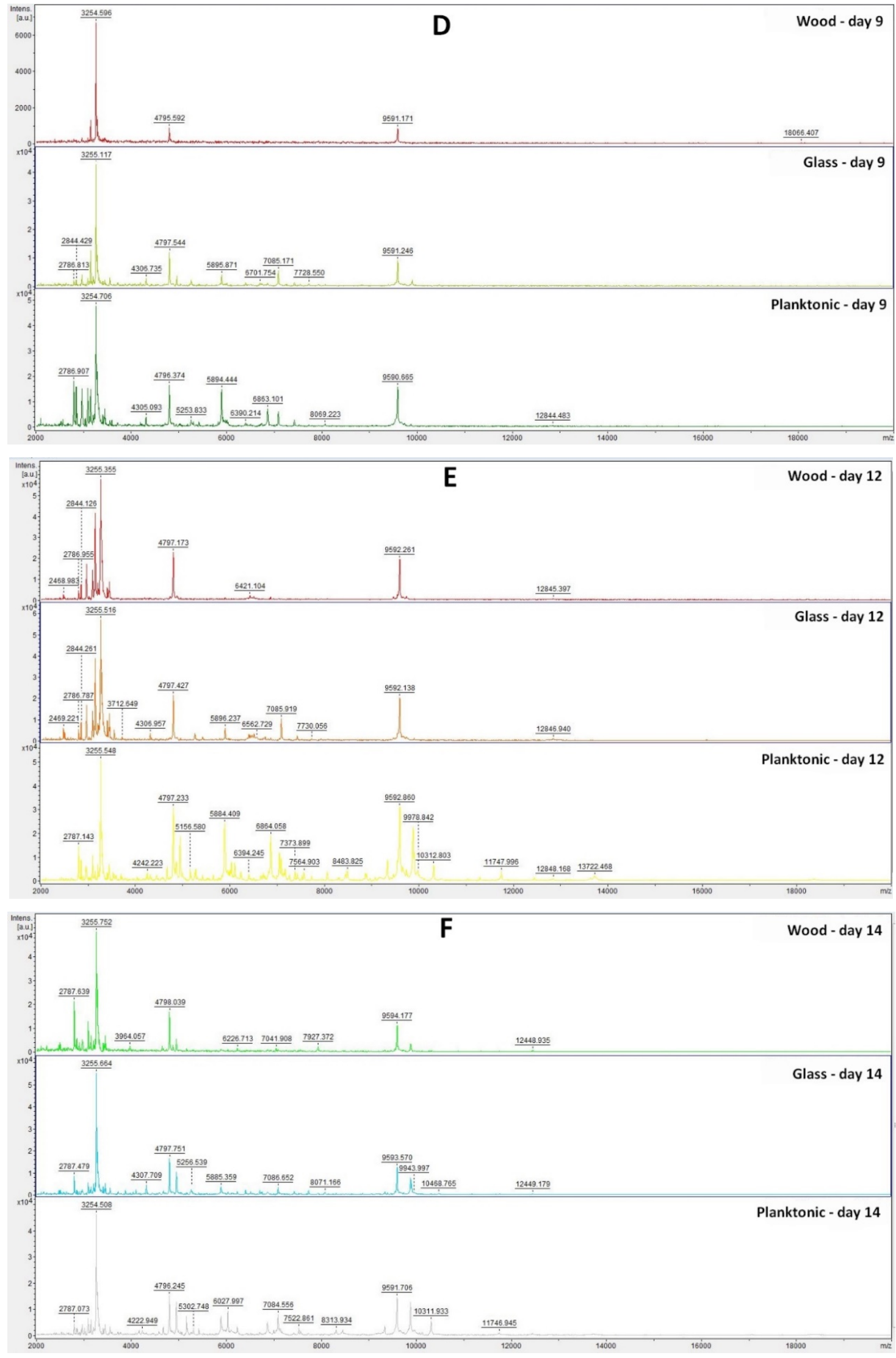

Figure 1. MALDI-TOF mass spectra of $P$. fluorescens biofilm development after TTEO exposition: (A) 3rd day; (B) 5th day; (C) 7th day; (D) 9th day; (E) 12th day; (F) 14th day. 


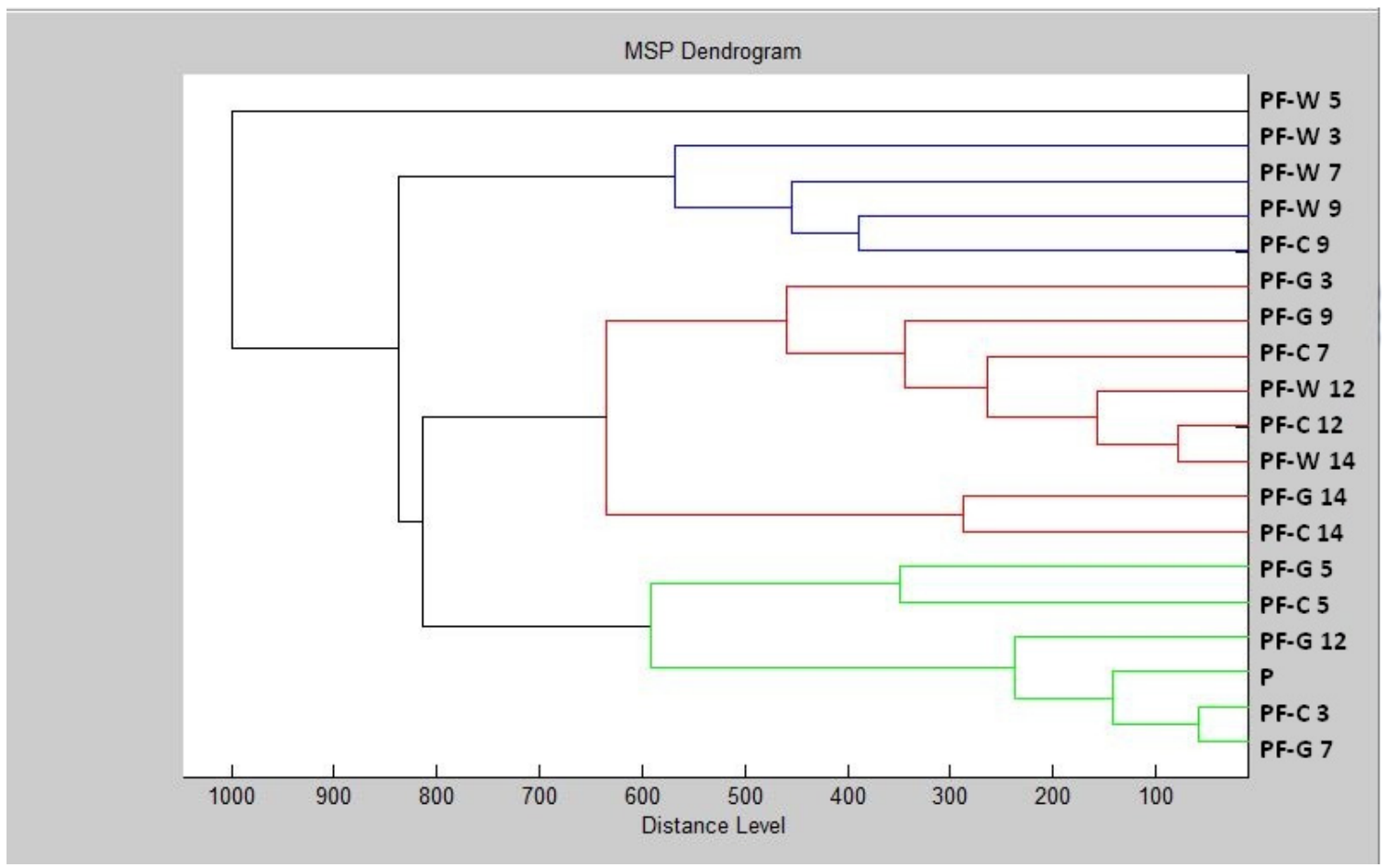

Figure 2. Dendrogram of $P$. fluorescens biofilm progress after TTEO exposition. PF-P. fluorescens; C-control; G-glass; W-wood; P-planktonic cells.

In the wood experimental group, we can observe significantly longer distances of MSP in comparison with the control group after the Day 7 of the experiment. On Day 9 of the experiment, the length of the MSP of the wood experimental group and the control group was the same. On Day 12, a reduction in the difference between the experimental and control groups was visible. On Day 14, there was a shortening of the MSP distance of the experimental group compared to the control. Based on this, we can conclude that the essential oil had an inhibitory effect on the biofilm of $P$. fluorescens up to 7-9 days, and after longer exposure, the biofilm adapted to adverse conditions.

The analyses of mass spectra of S. enterica biofilm showed changes in biofilm development from Day 3 after comparing TTEO exposition (Figure 3A). Structural changes were also visible on Days 5, 7, 9, 12, and 14 (Figure 3B-F). The most visible changes in protein structure were observed on Day 5 on the wood surface and on Day 9 on the glass surface.

Based on the constructed dendrogram (Figure 4) on Day 3 of the experiment, the MSP distance of the control group was the same as that of the experimental group on wood, and the experimental group on glass had a shorter distance than the control group. On Day 5, we recorded an increase in the distance of MSP experimental groups compared to the control group. On Day 7, the distances of MSP were shorter. On Day 9, both experimental groups had shorter distances than the control group. On Day 12, the distance between the MSP control group and the experimental group on wood remained significantly higher than the experimental group made of glass. On Day 14, on the other hand, we observed a significantly higher distance between the control group and the experimental group on glass, while the experimental group on wood had a significantly shorter distance from MSP.

The dendrogram showed that development of the $S$. enterica biofilm and protein degradation after TTEO exposure was not as certain as in P. aeruginosa, because the length of MSP between the control and experimental groups was not distinguished. While the mass spectra showed changes in protein structure, which was the result of biofilm degradation, the lengths of MPS did not reflect this result. The concentration of TTEO was too low to observe changes in biofilm formation, so the concentration of $0.1 \%$ TTEO is not sufficient to degrade biofilm at protein level and needs to be increased. 

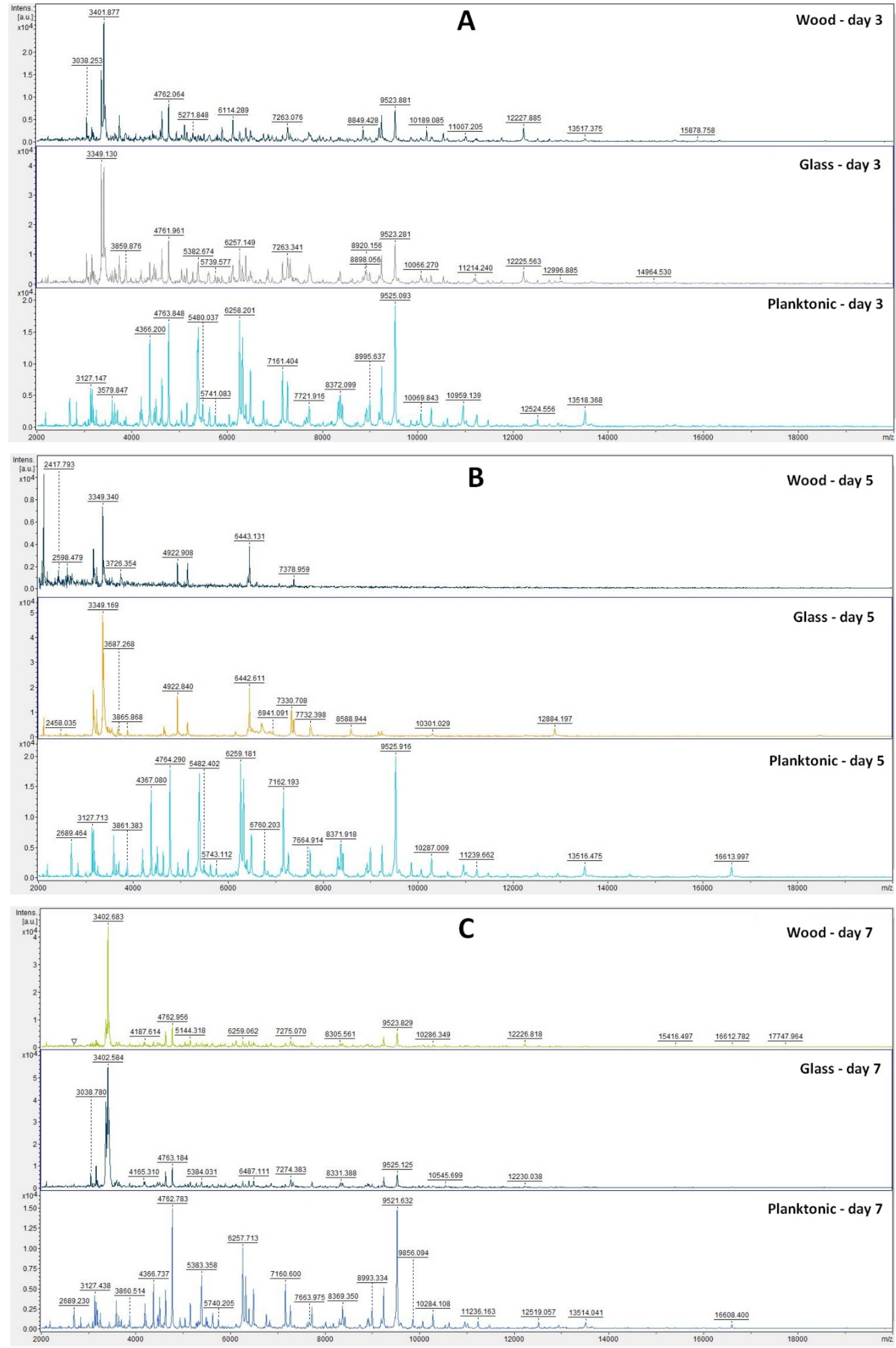

Figure 3. Cont. 

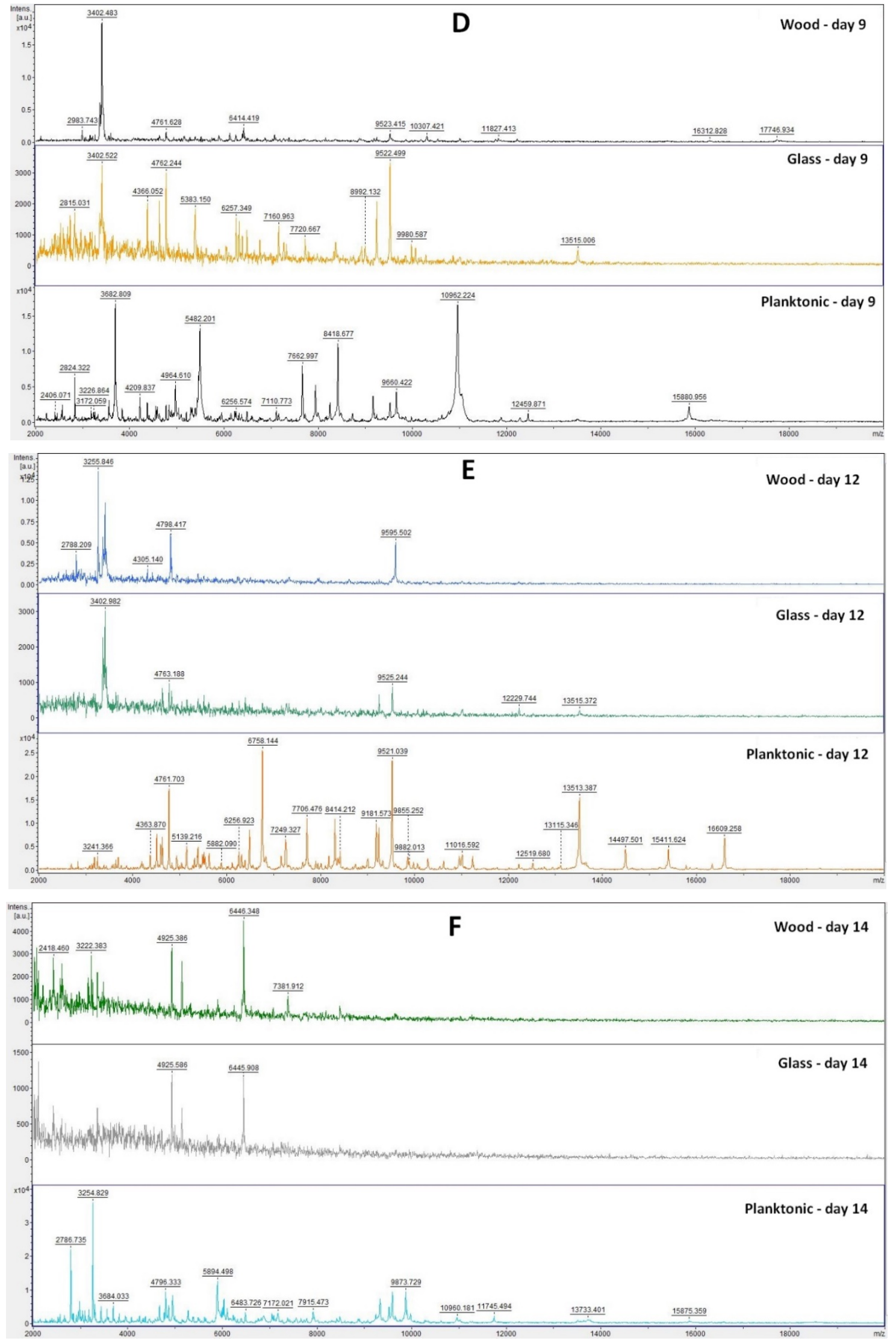

Figure 3. MALDI-TOF mass spectra of $S$. enterica biofilm development after TTEO exposition: (A) 3rd day; (B) 5th day; (C) 7th day; (D) 9th day; (E) 12th day; (F) 14th day. 


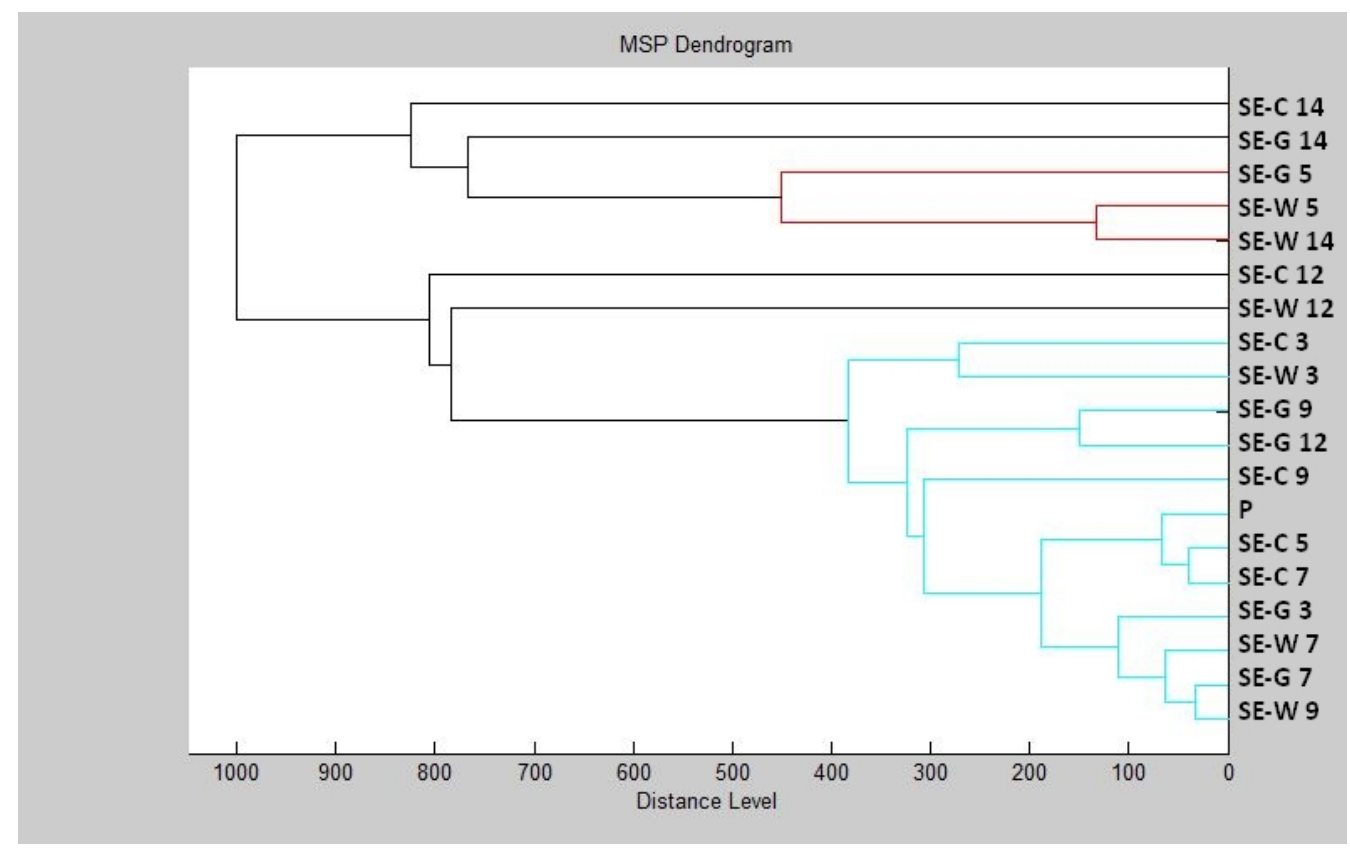

Figure 4. Dendrogram of $S$. enterica biofilm progress after TTEO exposition. SE-S. enterica; C-control; G-glass; W-wood; P-planktonic cells.

\section{Discussion}

The TTEO from Slovakia was rich in compounds and classified as a terpinen-4-ol chemotype, which is the most common chemotype. Among the terpinen-4-ol chemotypes, Liao et al. [30] observed the composition of TTEO terpinen-4-ol (40.09\%), $\gamma$-terpinene (21.85\%), $\alpha$-terpinene $(11.34 \%), \alpha$-terpineol (6.91\%), and $\alpha$-pinene $(5.86 \%)$. In our study, the TTEO contained almost the same amount of the main constituent terpinen-4-ol. Additionally, 1,8-cineole was among the dominant components. Our TTEO also had a lower amount of $\alpha$-terpinene. Noumi et al. [31] determined their TTEO by the composition of terpinen-4-ol (40.44\%), $\gamma$-terpinene (19.54\%), $\alpha$-terpinene (7.69\%), 1,8-cineole $(5.20 \%)$, $p$-cymene $(4.74 \%)$, and $\alpha$-terpineol (3.31\%). TTEO from France had a similar composition to the TTEO from our study. Brun et al. [32] analyzed ten TTEOs, all of which belonged to the terpinen-4-ol chemotype, with contents from approximately $42 \%$ to $48 \%$. These TTEOs also contained $\gamma$-terpinene from $18 \%$ to $25 \%$ and $\alpha$-terpinene from $8 \%$ to $12 \%$. Our TTEO had a lower content of all mentioned main components. The composition of TTEO in the study of Kim et al. [18] was terpinen-4-ol (43.2\%), $\gamma$-terpinene (20.6\%), and $\alpha$-terpinene (9.6\%), and Elmi et al. [33] analyzed $41.49 \%$ terpinen-4-ol, $20.55 \% \gamma$-terpinene, and $9.59 \% \alpha$-terpinene in their TTEO sample. Both authors determined a higher percentage of main components than our TTEO. Even though the presence of some constituents is lower than in other studies, our TTEO was comparable to other analyzed TTEOs. All major constituents meet the conditions of ISO norms, except the content of $\alpha$-terpinene should be over $5 \%$ [19]. Various conditions affect the quality of EOs such as geographical location, method of extraction, season of harvesting, or storage conditions.

The method of antioxidant activity is still evolving. Although expression of results has not been standardized, DPPH radical scavenging can validly describe the antioxidant capacity of essential oils [34]. Kim et al. [18] found that $10 \mu \mathrm{L} / \mathrm{mL}$ TTEO methanolic solution approached $80 \%$ antioxidant activity by the radical scavenging method, which was higher than our results. Zhang et al. [35] expressed the antioxidant activity as $\mathrm{EC}_{50}$ with the concentration of TTEO $48.35 \mu \mathrm{g} / \mathrm{mL}$ and described the TTEO as a potential antioxidant. Jeyakani and Rajalakshmi [36] measured antioxidant activity from 58.52 to $70.41 \%$, which was higher than our antioxidant activity. Zhao et al. [37] determined the antioxidant activity of methanolic solution as approximately $55 \%$. In our study, the antioxidant activity was slightly lower. Shah et al. [38] determined the antioxidant activity in the range of $39.56 \%$ to 
$60.44 \%$, dependent on concentration, which was in accordance with our study. Antioxidant activity is variable and related to chemical composition and can be affected by specific substances. Our TTEO had lower antioxidant properties than the mentioned authors, which can be caused by different chemical compositions. $\alpha$-Terpinene and $\alpha$-terpinolene greatly contribute to the antioxidant capacity of TTEO [18], but these components did not dominate in our TTEO.

The antimicrobial activity of TTEO determined by the disk diffusion method was evaluated Puvača et al. [39], who observed antimicrobial activity against Citrobacter koseri, Salmonella Typhi, and Escherichia coli in the range of 13 to $21 \mathrm{~mm}$. This antimicrobial activity was generally stronger than the results from our study. Esmael et al. [40] detected that TTEO was also active against antibiotic-resistant Staphylococcus aureus with an inhibition zone of $15.5 \mathrm{~mm}$. The inhibition zone of $S$. aureus from our study is half the size. Melo et al. [41] observed strong inhibition activity against S. enterica serovar Typhimurium, S. enterica serovar Enteritidis, E. coli, S. aureus, and E. faecalis in the range of $23.43-50.80 \mathrm{~mm}$. In this study, they used double the volume of EO compared to our study. Ergin et al. [42] measured the inhibition zones of six Candida species with inhibition zones of 14-42 mm, which were also higher than our inhibition zones. Li et al. [43] observed the inhibition zones of B. subtilis, C. albicans, M. luteus E. coli, S. enterica ser. Paratyphi B, S. aureus, S. saprophyticus, K. pneumonia, S. pyogenes in the range of $6.60-15.70 \mathrm{~mm}$. S. aureus had a lower inhibition zone $(6.60 \mathrm{~mm})$ than in our study. On the other hand, M. luteus was vulnerable to TTEO with an inhibition zone of $12.9 \mathrm{~mm}$. In our study, M. luteus was the most resistant among the tested microorganisms. The authors also stated that P. aeruginosa was resistant against TTEO, while in our study, its inhibition zone reached $6 \mathrm{~mm}$. B. subtilis and C. albicans had higher inhibition zones than in our study (12.6 and $15.7 \mathrm{~mm}$, respectively). Antimicrobial activity is also variable and dependent on factors such as chemical composition. The major active antimicrobial contributor in TTEO is terpinen-4-ol [44,45]. However, minor components also contribute to the antimicrobial efficacy of TTEO [46].

Puvača et al. [39] recorded the MIC of S. Typhi, C. koseri, and E. coli in the range of $2.7 \mathrm{mg} / \mathrm{mL}$ to $6.2 \mathrm{mg} / \mathrm{mL}$. They did not determine MIC 50 and MIC 90 values, as in our study, but they claimed good antimicrobial properties, which is in accordance with our study. Ziółkowska-Klinkosz et al. [47] determined the MIC as the concentration that completely inhibited the growth of anaerobic bacteria. They set the concentration in the range of $0.12-0.5 \mathrm{mg} / \mathrm{mL}$ which was considered good activity. The authors also declared that their TTEO was more effective against $\mathrm{G}^{+}$bacteria than $\mathrm{G}^{-}$. In our study, there were no differences between $\mathrm{G}^{+}$and $\mathrm{G}^{-}$bacteria. However, biofilm-forming $\mathrm{G}^{-}$bacteria and yeasts were less vulnerable to TTEO. Zhang et al. [35] determined the MIC of TTEO against S. aureus, E. coli, and P. aeruginosa at concentrations of 2,8 , and $12 \mathrm{mg} / \mathrm{mL}$, respectively. which was also considered good antimicrobial activity. Hammer et al. [48] tested the inhibition of 16 species of skin bacteria with TTEO; MIC 50 values were $0.25-0.5 \% v / v$, and MIC 90 values were $0.25-2 \% v / v$. Bagg et al. [49] observed the inhibition of TTEO against fluconazole and itraconazole-resistant yeast strains. The MIC 50 of TTEO $0.5 \% v / v$ for C. albicans and $0.25 \% v / v$ for C. glabrata and MIC 90 reached $1 \% v / v$ for both. Types of expression of MIC are also variable, but all authors declared good inhibitory activity of TTEO, which corresponds with our findings.

The influence of TTEO on biofilm formation was observed by Comin et al. [50], who reported the positive influence on inhibition of $P$. aeruginosa after application of TTEO nanoparticles. Kwieciński et al. [51] found out that TTEO can kill all clinical strains of S. aureus, both planktonic and biofilm-forming strains. They claimed that $0.5 \%$ TTEO killed $99 \%$ of bacteria after $60 \mathrm{~min}$. This concentration was more effective but also higher than in our study. Sadekuzzaman et al. [52] found out that TTEO reduced biofilm formation of E. coli O157:H7, L. monocytogenes, and Salmonella spp. at a concentration of $0.1 \%$, which is the same concentration used in our study. Sudjana et al. [53] observed that TTEO inhibited the adhesion of $C$. albicans and its biofilm formation on biotic and abiotic surfaces. Adhesion to polystyrene was significantly reduced at $0.25 \%$ TTEO, which was higher than 
the effective concentration in our study, as we needed only $0.1 \%$ TTEO to observe changes in protein structure. Al-Shuneigat [54] found that the TTEO product was able to reduce adherence to polystyrene in the biofilm-forming Staphylococcus strain. The reduction was significant at $625 \mathrm{ppm}$. Song et al. [55] found that TTEO can also effectively reduce the biofilm metabolism of $S$. mutans at a concentration of $0.125 \%$, which was comparable to our study. TTEO showed good growth inhibition against biofilm-forming bacteria, which means that TTEO can potentially be used in the food and pharmaceutical industry to prevent biofilm-forming strains.

Essential oils clearly have an effect on the production of low-molecular-weight protein that can be detected by MALDI-TOF MS. Božik et al. [56] detected ribosomal, membranerelated, cytosol-related, and DNA-related proteins and stress proteins, which changed the expression pattern in B. subtilis after essential oil components. Tang et al. [57] suggested that essential oil caused loss of membrane integrity, which led to inhibition of protein and biofilm synthesis at $S$. aureus.

MALDI-TOF MS is able to detect proteins in the mass range of 2-20 kDa, which belongs predominantly to housekeeping proteins, including ribosomal proteins, mitochondrial proteins, cold-shock and heat-shock proteins, and DNA-binding proteins $[58,59]$. Evaluation of biofilm-forming bacteria is not standard for biofilm formation evaluation. This fast method was described in $[60,61]$ and showed that valid results can be obtained. Few biofilm analyses have been performed by MALDI-TOF, but it seems to be a promising method for the future. Biofilm degradation was observed after exposition by C. sativum, T. serpyllum, and T. vulgaris. EO degradation of low-molecular-protein in the MALDI-TOF MS protein spectra of biofilm-forming bacteria was observed [62-64].

\section{Materials and Methods}

The tea tree essential oil was purchased from the Slovak company Hanus s.r.o. (Nitra, Slovakia). The essential oil was extracted by steam distillation of young branches and leaves of Melaleuca alternifolia.

\subsection{Microorganisms}

For the antimicrobial analyses, we used four Gram-positive bacteria (Bacillus subtilis CCM 1999, Enterococcus faecalis CCM 4224, Micrococcus luteus CCM 732, and Staphylococcus aureus subsp. aureus CCM 8223), four Gram-negative bacteria (Pseudomonas aeruginosa CCM 3955, Salmonella enterica subsp. enterica CCM 4420, Yersinia enterocolitica CCM 7204, and Serratia marcescens CCM 8587), and four yeasts (Candida albicans CCM 8261, Candida glabrata CCM 8270, Candida krusei CCM 8271, and Candida tropicalis CCM 8223), which were obtained from the Czech Collection of Microorganisms (Brno, Czech Republic). The biofilm-forming bacterial strains Pseudomonas fluorescens and Salmonella enterica were used for analyses of antibiofilm activity. P. fluorescens was isolated from fish, and S. enterica was isolated from chicken meat. Biofilm-forming bacteria were identified by $16 \mathrm{~S}$ rRNA sequencing and MALDI-TOF MS Biotyper.

\subsection{Analysis of Chemical Structure}

Chemical characterization of TTEO was performed by gas chromatography/mass spectrometry (GC/MS) and gas chromatography (GC-FID) using the Agilent $6890 \mathrm{~N}$ gas chromatograph (Agilent Technologies, Santa Clara, CA, USA) coupled to a 5975B quadrupole mass spectrometer (Agilent Technologies, Santa Clara, CA, USA). An HP-5MS capillary column $(30 \mathrm{~m} \times 0.25 \mathrm{~mm} \times 0.25 \mu \mathrm{m})$ was used. The temperature program was set from $60{ }^{\circ} \mathrm{C}$ to $150{ }^{\circ} \mathrm{C}\left(3{ }^{\circ} \mathrm{C} / \mathrm{min}\right.$ increasing rate $)$ and $150{ }^{\circ} \mathrm{C}$ to $280{ }^{\circ} \mathrm{C}\left(5^{\circ} \mathrm{C} /\right.$ minincreasing rate) with total run time $60 \mathrm{~min}$. The carrier gas was helium 5.0 with flow rate $1 \mathrm{~mL} / \mathrm{min}$. The split/splitless injector temperature was set at $280{ }^{\circ} \mathrm{C}$, and $1 \mu \mathrm{L}$ EO sample diluted in pentane was injected. Investigated samples were injected in the split mode with split ratio 40.8:1. Electron-impact mass spectrometric data (EI-MS; $70 \mathrm{eV}$ ) were acquired in scan mode over the $m / z$ range $35-550$. MS ion source and MS quadrupole temperatures were 
$230^{\circ} \mathrm{C}$ and $150{ }^{\circ} \mathrm{C}$, respectively. GC-FID analyses were performed on an Agilent $6890 \mathrm{~N}$ gas chromatograph coupled to an FID detector. Column and chromatographic conditions were the same as during GC-MS analysis. FID detector temperature was set at $300{ }^{\circ} \mathrm{C}$. The volatile constituents of EO were identified according to retention indices [65] were compared to reference spectra (Wiley and NIST databases). The retention indices were experimentally determined using the standard method of n-alkanes (C6-C34) retention times, injected under the same chromatographic conditions [66]. The percentages of the identified compounds (higher than $0.1 \%$ ) were derived from GC peak areas. The measurement was performed in triplicate.

\subsection{Antioxidant Activity}

The radical scavenging of 2,2-diphenyl-1-picrylhydrazyl (DPPH, Sigma Aldrich, Schnelldorf, Germany) was used to measure the antioxidant activity of TTEO. DPPH was dissolved in methanol to concentration $0.025 \mathrm{~g} / \mathrm{L}$ and was adjusted to absorbance 0.8 at wavelength $515 \mathrm{~nm}$ (by Glomax spectrophotometer, Promega Inc., Madison, WI, USA). A $5 \mu \mathrm{L}$ volume of EO sample was added to $195 \mu \mathrm{L}$ DPPH solution in a 96-well microplate and was incubated for $30 \mathrm{~min}$ in the dark with shaking at $1000 \mathrm{rpm}$. The percentage of DPPH inhibition was calculated according to the formula (A0 - AA) / A0 × 100, where A0 is the absorbance of DPPH with methanol, and AA is the absorbance of the sample. The standard reference Trolox (Sigma Aldrich, Schnelldorf, Germany) was used for calculation of total antioxidant capacity. Trolox was dissolved in methanol (Uvasol ${ }^{\circledR}$ for spectroscopy, Merck, Darmstadt, Germany) to the concentration range 0-100 $\mu \mathrm{g} / \mathrm{mL}$. Total antioxidant activity was expressed according to the calibration curve as $1 \mu \mathrm{g}$ Trolox to $1 \mathrm{~mL}$ EO sample (TEAC).

\subsection{Disk Diffusion Method}

The disk diffusion method was used for determination of TTEO antimicrobial activity. Bacterial inoculum was cultivated for $24 \mathrm{~h}$ on Tryptone soya agar (TSA, Oxoid, Basingstoke, UK) at $37{ }^{\circ} \mathrm{C}$, and yeast inoculum was cultivated on Sabouraud dextrose agar (SDA, Oxoid, Basingstoke, UK) at $25^{\circ} \mathrm{C}$. Microbial culture was adjusted with distilled water to optical density $0.5 \mathrm{McF}$ arland standard $\left(1.5 \times 10^{8} \mathrm{CFU} / \mathrm{mL}\right)$. A $100 \mu \mathrm{L}$ volume of bacterial culture was spread on Mueller-Hinton agar (MHA, Oxoid, Basingstoke, UK), and $100 \mu \mathrm{L}$ yeast culture was spread on Sabouraud dextrose agar (SDA, Oxoid, Basingstoke, UK). Subsequently, sterile $6 \mathrm{~mm}$ disks were saturated with $10 \mu \mathrm{L}$ TTEO and placed on the microbial suspension, and samples were incubated at $37^{\circ} \mathrm{C}$ for bacteria and $25^{\circ} \mathrm{C}$ for yeasts for $24 \mathrm{~h}$.

Inhibition zones were measured at three sides from the edge of the filter. The inhibition zone larger than $10 \mathrm{~mm}$ was determined as very strong antimicrobial activity, the $10-5 \mathrm{~mm}$ inhibition zone was determined as moderate activity, and the 5-1 mm inhibition zone was determined as weak activity. The antibiotics used as control were cefoxitin for $\mathrm{G}^{-}$ bacteria, gentamicin for $\mathrm{G}^{+}$bacteria, and fluconazole for yeasts. The method of evaluation of inhibition zones was also the same for biofilm-forming bacteria. Antimicrobial activity was measured in triplicate.

\subsection{Broth Microdilution Method}

Bacterial inoculum was cultivated for $24 \mathrm{~h}$ in Mueller-Hinton broth (MHB, Oxoid, Basingstoke, UK) at $37^{\circ} \mathrm{C}$, and yeast inoculum was cultivated on Sabouraud dextrose broth (SDA, Oxoid, Basingstoke, UK) at $25^{\circ} \mathrm{C}$. A $50 \mu \mathrm{L}$ volume of inoculum with optical density $0.5 \mathrm{McF}$ arland standard was added to a 96-well microplate. A $100 \mu \mathrm{L}$ volume of TTEO was added to the microbial suspension in final concentrations from $400 \mu \mathrm{L} / \mathrm{mL}$ to $0.2 \mu \mathrm{L} / \mathrm{mL}$. Samples were mixed incubated for $24 \mathrm{~h}$ at $25^{\circ} \mathrm{C}$ (yeast cultures) and $37^{\circ} \mathrm{C}$ (bacterial cultures) [67].

After $24 \mathrm{~h}$ incubation, the biofilm-forming bacteria were dyed with crystal violet. The medium with unattached cells was discarded. Biofilm was washed three times with 
distilled water. A $200 \mu \mathrm{L}$ volume of crystal violet $(0.1 \% w / v)$ was added, and samples were incubated for $15 \mathrm{~min}$. The solution was discarded, and samples were washed again. The biofilm was solubilized in $200 \mu \mathrm{L}$ acetic acid (33\%). The absorbance was measured at $570 \mathrm{~nm}[68]$.

MHB with EO was used as a negative control, and MHB with inoculum was used as a positive control. Absorbance was measured spectrophotometrically at the beginning of the experiment and after $24 \mathrm{~h}$ at $570 \mathrm{~nm}$. The analysis was prepared in triplicate.

\subsection{Analysis of Biofilm Degradation}

Degradation of the protein spectra during biofilm development was evaluated in biofilm-forming $P$. fluorescens and S. enterica. TTEO addition was evaluated with MALDITOF MS Biotyper. A $20 \mathrm{~mL}$ volume of MHB was added to $50 \mathrm{~mL}$ tubes. A $200 \mu \mathrm{L}$ volume of biofilm-forming bacteria was added. The tubes also contained the toothpick that simulated the wooden surface and the microscopic slide that simulated the glass surface. TTEO was added to experimental groups in $0.1 \%$ final concentration, and control samples were left untreated. The samples were incubated at $37{ }^{\circ} \mathrm{C}$ on a shaker with $170 \mathrm{rpm}$ and analyzed on Days 3, 5, 7, 9, 12, and 14. The biofilm samples were taken from glass and wooden surfaces with a sterile cotton swab and were added to the MALDI-TOF target plate. Planktonic cells were taken from $300 \mu \mathrm{L}$ culture medium. The bacterial suspension was centrifuged for $1 \mathrm{~min}$ at 12,000 rpm, and the supernatant was discarded. The pellet was three times washed in $30 \mu \mathrm{L}$ ultrapure water and centrifuged. After washing, planktonic cells were resuspended, and $1 \mu \mathrm{L}$ was applied to a target plate.

A $1 \mu \mathrm{L}$ volume of the $\alpha$-cyano-4-hydroxycinnamic acid matrix $(10 \mathrm{mg} / \mathrm{mL})$ was applied to the dried target plate with samples. MALDI-TOF MicroFlex (Bruker Daltonics) was used for analysis of biofilm protein structure. Spectra were recorded in linear and positive mode with a mass-to-charge ratio range of 200-2000. The protein spectra were obtained by automatic analysis, and the similarities of the spectra in one sample were used to generate the standard global spectrum (MSP). Nineteen MSP were generated from the spectra by MALDI Biotyper 3.0 and were grouped into dendrograms using Euclidean distance [69].

\subsection{Statistical Data Evaluation}

SAS ${ }^{\circledR}$ software was used for data processing. MIC values (concentration that caused $50 \%$ and $90 \%$ inhibition in bacterial growth) were determined by logit analysis.

\section{Conclusions}

The biological activity and chemical composition of TTEO was evaluated. The TTEO was a terpinen-4-ol chemotype that also contained $\gamma$-terpinene, 1,8 -cineole, and $p$-cymene. This TTEO can be used as a potential antioxidant. The best antimicrobial activity was observed against $E$. faecalis, and the minimum inhibitory concentration $C$. albicans showed better susceptibility to $\mathrm{G}^{+}$and $\mathrm{G}^{-}$bacteria than yeast and biofilm-forming bacteria. The TTEO was also effective against $P$. fluorescens biofilm formation, while $S$. enterica biofilm needs to be tested with higher concentrations of TTEO.

The TTEO from the Slovak Republic generally has good biological activity, which gives the potential for use in the food industry and medicine to prevent oxidation, inhibit the growth of bacteria, and inhibit the formation of biofilm.

Author Contributions: Conceptualization, P.B., L.G. and M.K.; data curation, P.B., L.G., N.L.V., M.V. and M.K.; methodology, P.B., L.G., N.L.V., M.V., E.T. and M.K.; supervision, M.K.; writing-original draft preparation, L.G., P.B., E.T., N.L.V., M.V. and M.K. All authors have read and agreed to the published version of the manuscript.

Funding: This research was funded by the grant APVV-20-0058 "The potential of the essential oils from aromatic plants for medical use and food preservation".

Institutional Review Board Statement: Not applicable. 
Informed Consent Statement: Not applicable.

Data Availability Statement: Data are contained within the article.

Acknowledgments: This work has been supported by the grants of the VEGA no. 1/0180/20.

Conflicts of Interest: The authors declare no conflict of interest.

\section{References}

1. Padovan, A.; Keszei, A.; Hassan, Y.; Krause, S.T.; Köllner, T.G.; Degenhardt, J.; Gershenzon, J.; Külheim, C.; Foley, W.J. Four Terpene Synthases Contribute to the Generation of Chemotypes in Tea Tree (Melaleuca alternifolia). BMC Plant Biol. 2017, 17, 160. [CrossRef] [PubMed]

2. Homer, L.E.; Leach, D.N.; Lea, D.; Slade Lee, L.; Henry, R.J.; Baverstock, P.R. Natural Variation in the Essential Oil Content of Melaleuca alternifolia Cheel (Myrtaceae). Biochem. Syst. Ecol. 2000, 28, 367-382. [CrossRef]

3. Doran, J.C.; Baker, G.R.; Williams, E.R.; Southwell, I.A.; Doran, J.C.; Baker, G.R.; Williams, E.R.; Southwell, I.A. Genetic Gains in Oil Yields after Nine Years of Breeding Melaleuca alternifolia (Myrtaceae). Aust. J. Exp. Agric. 2006, 46, 1521-1527. [CrossRef]

4. Malhi, H.K.; Tu, J.; Riley, T.V.; Kumarasinghe, S.P.; Hammer, K.A. Tea Tree Oil Gel for Mild to Moderate Acne; a 12 Week Uncontrolled, Open-Label Phase II Pilot Study. Australas. J. Dermatol. 2017, 58, 205-210. [CrossRef]

5. Wallengren, J. Tea Tree Oil Attenuates Experimental Contact Dermatitis. Arch. Dermatol. Res. 2011, 303, 333-338. [CrossRef]

6. Chin, K.B.; Cordell, B. The Effect of Tea Tree Oil (Melaleuca alternifolia) on Wound Healing Using a Dressing Model. J. Altern. Complement. Med. 2013, 19, 942-945. [CrossRef]

7. Loughlin, R.; Gilmore, B.F.; McCarron, P.A.; Tunney, M.M. Comparison of the Cidal Activity of Tea Tree Oil and Terpinen-4-Ol against Clinical Bacterial Skin Isolates and Human Fibroblast Cells. Lett. Appl. Microbiol. 2008, 46, 428-433. [CrossRef]

8. Mertas, A.; Garbusińska, A.; Szliszka, E.; Jureczko, A.; Kowalska, M.; Król, W. The Influence of Tea Tree Oil (Melaleuca alternifolia) on Fluconazole Activity against Fluconazole-Resistant Candida albicans Strains. Biomed. Res. Int. 2015, 2015, 590470. [CrossRef]

9. Hart, P.H.; Brand, C.; Carson, C.F.; Riley, T.V.; Prager, R.H.; Finlay-Jones, J.J. Terpinen-4-Ol, the Main Component of the Essential Oil of Melaleuca alternifolia (Tea Tree Oil), Suppresses Inflammatory Mediator Production by Activated Human Monocytes. Inflamm. Res. 2000, 49, 619-626. [CrossRef]

10. Shapira, S.; Pleban, S.; Kazanov, D.; Tirosh, P.; Arber, N. Terpinen-4-Ol: A Novel and Promising Therapeutic Agent for Human Gastrointestinal Cancers. PLoS ONE 2016, 11, e0156540. [CrossRef]

11. Li, G.-X.; Liu, Z.-Q. Unusual Antioxidant Behavior of $\alpha$ - and $\gamma$-Terpinene in Protecting Methyl Linoleate, DNA, and Erythrocyte. J. Agric. Food Chem. 2009, 57, 3943-3948. [CrossRef] [PubMed]

12. Aydin, E.; Türkez, H.; Taşdemir, Ş. Anticancer and Antioxidant Properties of Terpinolene in Rat Brain Cells. Arh. Hig. Rada. Toksikol. 2013, 64, 415-424. [CrossRef]

13. Galan, D.M.; Ezeudu, N.E.; Garcia, J.; Geronimo, C.A.; Berry, N.M.; Malcolm, B.J. Eucalyptol (1,8-Cineole): An Underutilized Ally in Respiratory Disorders? J. Essent. Oil Res. 2020, 32, 103-110. [CrossRef]

14. Cai, Z.-M.; Peng, J.-Q.; Chen, Y.; Tao, L.; Zhang, Y.-Y.; Fu, L.-Y.; Long, Q.-D.; Shen, X.-C. 1,8-Cineole: A Review of Source, Biological Activities, and Application. J. Asian Nat. Prod. Res. 2021, 23, 938-954. [CrossRef]

15. Vijayakumar, K.; Manigandan, V.; Jeyapragash, D.; Bharathidasan, V.; Anandharaj, B.; Sathya, M. Eucalyptol Inhibits Biofilm Formation of Streptococcus pyogenes and Its Mediated Virulence Factors. J. Med. Microbiol. 2020, 69, 1308-1318. [CrossRef] [PubMed]

16. Marchese, A.; Arciola, C.R.; Barbieri, R.; Silva, A.S.; Nabavi, S.F.; Tsetegho Sokeng, A.J.; Izadi, M.; Jafari, N.J.; Suntar, I.; Daglia, M.; et al. Update on Monoterpenes as Antimicrobial Agents: A Particular Focus on p-Cymene. Materials 2017, 10, 947. [CrossRef] [PubMed]

17. Yasin, M.; Younis, A.; Javed, T.; Akram, A.; Ahsan, M.; Shabbir, R.; Ali, M.M.; Tahir, A.; El-Ballat, E.M.; Sheteiwy, M.S.; et al. River Tea Tree Oil: Composition, Antimicrobial and Antioxidant Activities, and Potential Applications in Agriculture. Plants 2021, 10, 2105. [CrossRef]

18. Kim, H.-J.; Chen, F.; Wu, C.; Wang, X.; Chung, H.Y.; Jin, Z. Evaluation of Antioxidant Activity of Australian Tea Tree (Melaleuca alternifolia) Oil and Its Components. J. Agric. Food Chem. 2004, 52, 2849-2854. [CrossRef]

19. Carson, C.F.; Hammer, K.A.; Riley, T.V. Melaleuca alternifolia (Tea Tree) Oil: A Review of Antimicrobial and Other Medicinal Properties. Clin. Microbiol. Rev. 2006, 19, 50-62. [CrossRef]

20. Cox, S.D.; Mann, C.M.; Markham, J.L.; Gustafson, J.E.; Warmington, J.R.; Wyllie, S.G. Determining the Antimicrobial Actions of Tea Tree Oil. Molecules 2001, 6, 87-91. [CrossRef]

21. Jafri, H.; Ansari, F.; Ahmad, I. Prospects of Essential Oils in Controlling Pathogenic Biofilm. In New Look to Phytomedicine; Academic Press: London, UK, 2019; pp. 203-236. [CrossRef]

22. Brożyna, M.; Paleczny, J.; Kozłowska, W.; Chodaczek, G.; Dudek-Wicher, R.; Felińczak, A.; Gołębiewska, J.; Górniak, A.; Junka, A. The Antimicrobial and Antibiofilm In Vitro Activity of Liquid and Vapour Phases of Selected Essential Oils against Staphylococcus aureus. Pathogens 2021, 10, 1207. [CrossRef] [PubMed]

23. Liu, T.; Wang, J.; Gong, X.; Wu, X.; Liu, L.; Chi, F. Rosemary and Tea Tree Essential Oils Exert Antibiofilm Activities In Vitro against Staphylococcus aureus and Escherichia coli. J. Food Prot. 2020, 83, 1261-1267. [CrossRef] [PubMed] 
24. Francisconi, R.S.; Huacho, P.M.M.; Tonon, C.C.; Bordini, E.A.F.; Correia, M.F.; de Sardi, J.C.O.; Spolidorio, D.M.P. Antibiofilm Efficacy of Tea Tree Oil and of Its Main Component Terpinen-4-Ol against Candida albicans. Braz. Oral Res. 2020, 34, e050. [CrossRef] [PubMed]

25. Baum, M.M.; Kainović, A.; O'Keeffe, T.; Pandita, R.; McDonald, K.; Wu, S.; Webster, P. Characterization of Structures in Biofilms Formed by a Pseudomonas fluorescens Isolated from Soil. BMC Microbiol. 2009, 9, 103. [CrossRef]

26. Kumar, H.; Franzetti, L.; Kaushal, A.; Kumar, D. Pseudomonas fluorescens: A Potential Food Spoiler and Challenges and Advances in Its Detection. Ann. Microbiol. 2019, 69, 873-883. [CrossRef]

27. Borges, K.A.; Furian, T.Q.; de Souza, S.N.; Menezes, R.; de Lima, D.A.; Fortes, F.B.B.; Salle, C.T.P.; Moraes, H.L.S.; Nascimento, V.P. Biofilm Formation by Salmonella enteritidis and Salmonella Typhimurium Isolated from Avian Sources Is Partially Related with Their In Vivo Pathogenicity. Microb. Pathog. 2018, 118, 238-241. [CrossRef]

28. de Webber, B.; Oliveira, A.P.; Pottker, E.S.; Daroit, L.; Levandowski, R.; dos Santos, L.R.; do Nascimento, V.P.; Rodrigues, L.B. Salmonella enteritidis Forms Biofilm under Low Temperatures on Different Food Industry Surfaces. Cienc. Rural 2019, 49, e20181022. [CrossRef]

29. Dantas, S.T.A.; Rossi, B.F.; Bonsaglia, E.C.R.; Castilho, I.G.; Hernandes, R.T.; Fernandes, A.; Rall, V.L.M. Cross-Contamination and Biofilm Formation by Salmonella enterica Serovar Enteritidis on Various Cutting Boards. Foodborne Pathog. Dis. 2018, 15, 81-85. [CrossRef]

30. Liao, M.; Xiao, J.-J.; Zhou, L.-J.; Yao, X.; Tang, F.; Hua, R.-M.; Wu, X.-W.; Cao, H.-Q. Chemical Composition, Insecticidal and Biochemical Effects of Melaleuca alternifolia Essential Oil on the Helicoverpa armigera. J. Appl. Entomol. 2017, 141, 721-728. [CrossRef]

31. Noumi, E.; Snoussi, M.; Hajlaoui, H.; Trabelsi, N.; Ksouri, R.; Valentin, E.; Bakhrouf, A. Chemical Composition, Antioxidant and Antifungal Potential of Melaleuca alternifolia (Tea Tree) and Eucalyptus globulus Essential Oils against Oral Candida Species. J. Med. Plants Res. 2011, 5, 4147-4156. [CrossRef]

32. Brun, P.; Bernabè, G.; Filippini, R.; Piovan, A. In Vitro Antimicrobial Activities of Commercially Available Tea Tree (Melaleuca alternifolia) Essential Oils. Curr. Microbiol. 2019, 76, 108-116. [CrossRef] [PubMed]

33. Elmi, A.; Ventrella, D.; Barone, F.; Carnevali, G.; Filippini, G.; Pisi, A.; Benvenuti, S.; Scozzoli, M.; Bacci, M.L. In Vitro Effects of Tea Tree Oil (Melaleuca alternifolia Essential Oil) and Its Principal Component Terpinen-4-Ol on Swine Spermatozoa. Molecules 2019, 24, 1071. [CrossRef] [PubMed]

34. Kedare, S.B.; Singh, R.P. Genesis and Development of DPPH Method of Antioxidant Assay. J. Food Sci. Technol. $2011,48,412-422$. [CrossRef] [PubMed]

35. Zhang, X.; Guo, Y.; Guo, L.; Jiang, H.; Ji, Q. In Vitro Evaluation of Antioxidant and Antimicrobial Activities of Melaleuca alternifolia Essential Oil. Biomed. Res. Int. 2018, 2018, 2396109. [CrossRef] [PubMed]

36. Jeyakani, M.; Rajalakshmi, M. Antioxidant Activity, Total Phenolic Content of Essential Oils, and Extract Determined from Natural Leaves, In-Vitro Leaves, and Callus Sources of Melaleuca alternifolia-A Comparative Study. Asian J. Pharm. Clin. Res. 2021, 14, 141-143. [CrossRef]

37. Zhao, Q.; Bowles, E.J.; Zhang, H.-Y. Antioxidant Activities of Eleven Australian Essential Oils. Nat. Prod. Commun. 2008, 3, 837-842. [CrossRef]

38. Shah, G.; Dhawan, R.K. Antioxidant Activity of Methanol Extract Leaves of Melaleuca alternifolia (Maiden \& Betche) Cheel. J. Mater. Environ. Sci. 2019, 10, 1286-1295.

39. Puvača, N.; Milenković, J.; Galonja Coghill, T.; Bursić, V.; Petrović, A.; Tanasković, S.; Pelić, M.; Ljubojević Pelić, D.; Miljković, T. Antimicrobial Activity of Selected Essential Oils against Selected Pathogenic Bacteria: In Vitro Study. Antibiotics 2021, 10, 546. [CrossRef]

40. Esmael, A.; Hassan, M.G.; Amer, M.M.; Abdelrahman, S.; Hamed, A.M.; Abd-raboh, H.A.; Foda, M.F. Antimicrobial Activity of Certain Natural-Based Plant Oils against the Antibiotic-Resistant Acne Bacteria. Saudi J. Biol. Sci. 2020, 27, 448-455. [CrossRef]

41. Melo, A.D.B.; Amaral, A.F.; Schaefer, G.; Luciano, F.B.; de Andrade, C.; Costa, L.B.; Rostagno, M.H. Antimicrobial Effect against Different Bacterial Strains and Bacterial Adaptation to Essential Oils Used as Feed Additives. Can. J. Vet. Res. 2015, 79, 285-289.

42. Ergin, A.; Arikan, S. Comparison of Microdilution and Disc Diffusion Methods in Assessing the In Vitro Activity of Fluconazole and Melaleuca alternifolia (Tea Tree) Oil against Vaginal Candida Isolates. J. Chemother. 2002, 14, 465-472. [CrossRef] [PubMed]

43. Li, X.; Shen, D.; Zang, Q.; Qiu, Y.; Yang, X. Chemical Components and Antimicrobial Activities of Tea Tree Hydrosol and Their Correlation with Tea Tree Oil. Nat. Prod. Commun. 2021, 16, 1934578X211038390. [CrossRef]

44. Mondello, F.; De Bernardis, F.; Girolamo, A.; Cassone, A.; Salvatore, G. In Vivo Activity of Terpinen-4-Ol, the Main Bioactive Component of Melaleuca alternifolia Cheel (Tea Tree) Oil against Azole-Susceptible and -Resistant Human Pathogenic Candida Species. BMC Infect. Dis. 2006, 6, 158. [CrossRef] [PubMed]

45. Cordeiro, L.; Figueiredo, P.; Souza, H.; Sousa, A.; Andrade-Júnior, F.; Medeiros, D.; Nóbrega, J.; Silva, D.; Martins, E.; Barbosa-Filho, J.; et al. Terpinen-4-Ol as an Antibacterial and Antibiofilm Agent against Staphylococcus aureus. Int. J. Mol. Sci. 2020, 21, 4531. [CrossRef]

46. Lee, C.-J.; Chen, L.-W.; Chen, L.-G.; Chang, T.-L.; Huang, C.-W.; Huang, M.-C.; Wang, C.-C. Correlations of the Components of Tea Tree Oil with Its Antibacterial Effects and Skin Irritation. J. Food Drug Anal. 2013, 21, 169-176. [CrossRef]

47. Ziółkowska-Klinkosz, M.; Kedzia, A.; Meissner, H.O.; Kedzia, A.W. Evaluation of the Tea Tree Oil Activity to Anaerobic Bacteria-In Vitro Study. Acta Pol. Pharm. 2016, 73, 389-394. 
48. Hammer, K.A.; Carson, C.F.; Riley, T.V. Susceptibility of Transient and Commensal Skin Flora to the Essential Oil of Melaleuca alternifolia (Tea Tree Oil). Am. J. Infect. Control 1996, 24, 186-189. [CrossRef]

49. Bagg, J.; Jackson, M.S.; Petrina Sweeney, M.; Ramage, G.; Davies, A.N. Susceptibility to Melaleuca alternifolia (Tea Tree) Oil of Yeasts Isolated from the Mouths of Patients with Advanced Cancer. Oral Oncol. 2006, 42, 487-492. [CrossRef]

50. Comin, V.M.; Lopes, L.Q.S.; Quatrin, P.M.; de Souza, M.E.; Bonez, P.C.; Pintos, F.G.; Raffin, R.P.; de Vaucher, R.A.; Martinez, D.S.T.; Santos, R.C.V. Influence of Melaleuca alternifolia Oil Nanoparticles on Aspects of Pseudomonas aeruginosa Biofilm. Microb. Pathog. 2016, 93, 120-125. [CrossRef]

51. Kwieciński, J.; Eick, S.; Wójcik, K. Effects of Tea Tree (Melaleuca alternifolia) Oil on Staphylococcus aureus in Biofilms and Stationary Growth Phase. Int. J. Antimicrob. Agents 2009, 33, 343-347. [CrossRef]

52. Sadekuzzaman, M.; Mizan, M.F.R.; Kim, H.-S.; Yang, S.; Ha, S.-D. Activity of Thyme and Tea Tree Essential Oils against Selected Foodborne Pathogens in Biofilms on Abiotic Surfaces. LWT 2018, 89, 134-139. [CrossRef]

53. Sudjana, A.N.; Carson, C.F.; Carson, K.C.; Riley, T.V.; Hammer, K.A. Candida albicans Adhesion to Human Epithelial Cells and Polystyrene and Formation of Biofilm Is Reduced by Sub-Inhibitory Melaleuca alternifolia (Tea Tree) Essential Oil. Med. Mycol. 2012, 50, 863-870. [CrossRef] [PubMed]

54. Al-Shuneigat, J.; Cox, S.D.; Markham, J.L. Effects of a Topical Essential Oil-Containing Formulation on Biofilm-Forming CoagulaseNegative Staphylococci. Lett. Appl. Microbiol. 2005, 41, 52-55. [CrossRef] [PubMed]

55. Song, Y.-M.; Zhou, H.-Y.; Wu, Y.; Wang, J.; Liu, Q.; Mei, Y.-F. In Vitro Evaluation of the Antibacterial Properties of Tea Tree Oil on Planktonic and Biofilm-Forming Streptococcus mutans. AAPS PharmSciTech 2020, 21, 227. [CrossRef] [PubMed]

56. Božik, M.; Cejnar, P.; Šašková, M.; Nový, P.; Maršík, P.; Klouček, P. Stress Response of Escherichia coli to Essential Oil ComponentsInsights on Low-Molecular-Weight Proteins from MALDI-TOF. Sci. Rep. 2018, 8, 13042. [CrossRef]

57. Tang, C.; Chen, J.; Zhang, L.; Zhang, R.; Zhang, S.; Ye, S.; Zhao, Z.; Yang, D. Exploring the Antibacterial Mechanism of Essential Oils by Membrane Permeability, Apoptosis and Biofilm Formation Combination with Proteomics Analysis against Methicillin-Resistant Staphylococcus aureus. Int. J. Med. Microbiol. 2020, 310, 151435. [CrossRef]

58. Singhal, N.; Kumar, M.; Kanaujia, P.K.; Virdi, J.S. MALDI-TOF Mass Spectrometry: An Emerging Technology for Microbial Identification and Diagnosis. Front. Microbiol. 2015, 6, 791. [CrossRef]

59. Murray, P.R. What Is New in Clinical Microbiology-Microbial Identification by MALDI-TOF Mass Spectrometry. J. Mol. Diagn. 2012, 14, 419-423. [CrossRef]

60. Stîngu, C.S.; Rodloff, A.C.; Jentsch, H.; Schaumann, R.; Eschrich, K. Rapid Identification of Oral Anaerobic Bacteria Cultivated from Subgingival Biofilm by MALDI-TOF-MS. Oral Microbiol. Immunol. 2008, 23, 372-376. [CrossRef]

61. Kırmusaoğlu, S. Antimicrobials, Antibiotic Resistance, Antibiofilm Strategies and Activity Methods; Intechopen: London, UK, 2019. [CrossRef]

62. Kačániová, M.; Galovičová, L.; Ivanišová, E.; Vukovic, N.L.; Štefániková, J.; Valková, V.; Borotová, P.; Žiarovská, J.; Terentjeva, M.; Felšöciová, S.; et al. Antioxidant, Antimicrobial and Antibiofilm Activity of Coriander (Coriandrum sativum L.) Essential Oil for Its Application in Foods. Foods 2020, 9, 282. [CrossRef]

63. Galovičová, L.; Borotová, P.; Valková, V.; Vukovic, N.L.; Vukic, M.; Terentjeva, M.; Štefániková, J.; Ď́úranová, H.; Kowalczewski, P.Ł.; Kačániová, M. Thymus serpyllum Essential Oil and Its Biological Activity as a Modern Food Preserver. Plants 2021, 10, 1416. [CrossRef] [PubMed]

64. Galovičová, L.; Borotová, P.; Valková, V.; Vukovic, N.L.; Vukic, M.; Štefániková, J.; Ďúranová, H.; Kowalczewski, P.Ł.; Čmiková, N.; Kačániová, M. Thymus vulgaris Essential Oil and Its Biological Activity. Plants 2021, 10, 1959. [CrossRef] [PubMed]

65. Adams, R.P. Identification of Essential Oil Components by Gas Chromatography/Mass Spectrometry. In Identification of Essential Oil Components by Gas Chromatography/Mass Spectrometry; Allured Publishing Corporation: Carol Streem, IL, USA, 2007.

66. van Den Dool, H.; Kratz, P.D. A Generalization of the Retention Index System Including Linear Temperature Programmed Gas-Liquid Partition Chromatography. J. Chromatogr. A 1963, 11, 463-471. [CrossRef]

67. Wiegand, I.; Hilpert, K.; Hancock, R.E.W. Agar and Broth Dilution Methods to Determine the Minimal Inhibitory Concentration (MIC) of Antimicrobial Substances. Nat. Protoc. 2008, 3, 163-175. [CrossRef]

68. Hassan, A.; Usman, J.; Kaleem, F.; Omair, M.; Khalid, A.; Iqbal, M. Evaluation of Different Detection Methods of Biofilm Formation in the Clinical Isolates. Braz. J. Infect. Dis. 2011, 15, 305-311. [CrossRef]

69. Pereira, F.D.E.S.; Bonatto, C.C.; Lopes, C.A.P.; Pereira, A.L.; Silva, L.P. Use of MALDI-TOF Mass Spectrometry to Analyze the Molecular Profile of Pseudomonas aeruginosa Biofilms Grown on Glass and Plastic Surfaces. Microb. Pathog. 2015, 86, 32-37. [CrossRef] 